\title{
Research Communication Regulation of Annexin I in Rheumatoid Synovial Cells by Glucocorticoids and Interleukin-1
}

\author{
Eric F. Morand, Pam Hall, Paul Hutchinson, and Yuan H.Yang \\ Centre for Inflammatory Diseases, Monash Institute for Medical Research, Monash Medical Centre, \\ Locked Bag No 29, Clayton Victoria 3168, Australia
}

Received 6 January 2006; Revised 23 January 2006; Accepted 23 January 2006

\begin{abstract}
The glucocorticoid (GC)-induced antiinflammatory molecule annexin I is expressed in leukocytes and has antiinflammatory effects in animal models of arthritis, but the expression of annexin I in rheumatoid arthritis (RA) fibroblast-like synoviocytes (FLS) is unknown. We report the constitutive and dexamethasone (DEX)-inducible expression of annexin I in RA FLS. DEX increased FLS annexin I protein translocation and mRNA expression. Interleukin (IL)- $1 \beta$ also induced annexin I translocation and mRNA but also increased intracellular protein. DEX and IL-1 had additive effects on annexin I mRNA, but DEX inhibited the inducing effect of IL- $1 \beta$ on cell surface annexin I. These results indicate that glucocorticoids and IL- $1 \beta$ upregulate the synthesis and translocation of annexin I in RA FLS, but interdependent signalling pathways are involved.
\end{abstract}

Copyright (C) 2006 Eric F. Morand et al. This is an open access article distributed under the Creative Commons Attribution License, which permits unrestricted use, distribution, and reproduction in any medium, provided the original work is properly cited.

\section{INTRODUCTION}

Glucocorticoids have been used in the treatment of human rheumatoid arthritis (RA) for fifty years see [1], but their mechanisms of action remain incompletely understood [2].

Glucocorticoids induce the synthesis and cell surface translocation of annexin I (also known as lipocortin 1), a $37 \mathrm{kD}$ member of the annexin superfamily of calcium and phospholipid binding proteins [3-5]. Antagonism of annexin I worsens inflammation [6-10], suggesting annexin I is a key participant in the antiinflammatory actions of glucocorticoids $[2,11]$.

Annexin I has been demonstrated in human blood leukocytes and RA tissue $[12,13]$. It exerts a constitutive inhibitory influence, and mediates the inhibitor effects of glucocorticoids, in rodent models of RA $[3,9,10,14-16]$. Regulated expression of functionally active cell surface annexin I binding sites has been reported in human RA fibroblastlike synoviocytes (FLS) $[17,18]$. Despite this, the expression and regulation of annexin I in FLS has not been reported. The present study was designed to examine the expression of annexin I in RA FLS, and to examine the regulation of FLS annexin I by glucocorticoids and interleukin (IL) $-1 \beta$.

\section{MATERIALS AND METHODS}

\section{Human synovial fibroblast culture}

All patients met American College of Rheumatology criteria for the classification of RA [19]. Cultured FLS were grown from synovial specimens surgically excised from knee, hip, and shoulder joints of patients with RA, as described in [20]. Briefly, synovial fragments $(2-3 \mathrm{~mm})$ were placed into $50 \mathrm{~mL}$ (per $2 \mathrm{~g}$ ) of enzyme solution containing $1 \mathrm{mg} / \mathrm{mL}$ Dispase (0.5 U/mg, Boehringer Mannheim, Sydney, Australia), $1 \mathrm{mg} / \mathrm{mL}$ collagenase (type II, $1 / \mathrm{mg}$; Sigma, St Louis, Mich), and $1 \mathrm{mg} / \mathrm{mL}$ DNase type I. (2, 000 units/mL; Boehringer Mannheim) in $\mathrm{Ca}++$ and $\mathrm{Mg}++$ free Hanks' balanced salt solution (HBSS, ICN Laboratories, UK) stirred for 1 hour at $37^{\circ} \mathrm{C}$. The digests were filtered and washed. Cells at a concentration of $10^{6}-10^{7} / \mathrm{mL}$ were placed in fresh RPMI $/ 10 \%$ FCS and cultured at $37^{\circ} \mathrm{C}, 5 \% \mathrm{CO}_{2}$. At the third passage, cells were frozen in liquid nitrogen at $10^{6} / \mathrm{mL}$ in RPMI $/ 20 \%$ FCS containing $10 \%$ dimethylsulfoxide (Ajax Chemicals, Sydney, Australia). Thawed cells were used in experiments between passages 5-8. Cells were cultured in RPMI $10 \%$ FCS and treated with dexamethasone (DEX) $\left(10^{-8}-10^{-7} \mathrm{M}\right)$ and/or IL- $1 \beta(1 \mathrm{ng} / \mathrm{mL})$ for up to 24 hours. 


\section{Analysis of cell surface annexin I}

Cell surface annexin I was obtained by washing cell monolayers with PBS containing $10 \mathrm{mM}$ EDTA, as described in [14]. Briefly, cell monolayers at $2 \times 10^{5} / \mathrm{mL}$ were washed with PBS and then with PBS containing 10 mM EDTA for 3-5 minutes at room temperature. Total protein was concentrated 10 -fold by centrifuge cryo-evaporation (Jouan, St Nazaire, France), and resuspended in $20 \mu \mathrm{l}$ of PBS for subsequent Western blotting with a specific antihuman annexin I monoclonal antibody $(\mathrm{mAb})$. Proteins were isolated by $12 \%$ Tris-HCL gel and transferred onto nitrocellulose membrane. The nitrocellulose was blocked for 1 hour in 5\% skim milk in Tris buffer. The membrane was subsequently incubated with $1 \mu \mathrm{g} / \mathrm{mL}$ of anti-annexin I mAb and HRP-conjugated rabbit antimouse IgG (diluted $1: 3000$ ). The blot was finally developed using a chemiluminescence system (ECL). The molecular masses of the annexin I-positive immunoreactive bands were determined by comparison with the migration of molecular mass standards. Recombinant annexin I was a generous gift from Dr Y Giga-Hama, Osaka, Japan, and was assessed as a standard. Differences in blot density were confirmed using NIH Image (Bethesda, Md).

\section{Flow cytometric detection of annexin I}

Intracellular expression of human synovial fibroblast annexin I was detected using permeabilization flow cytometry using a Cytomation MoFlo flow cytometer (Cytomation, Fort Collins, Colo, USA), as described in [21]. Briefly, cells were fixed and permeabilized by suspension in $2 \%$ paraformaldehyde and $0.2 \%$ saponin (Sigma)/PBS, then incubated sequentially with annexin I (or control) $\mathrm{mAb}$ and FITC-conjugated sheep antimouse IgG. Results are expressed as mean fluorescence intensity (MFI) after subtraction of MFI obtained with isotype-control antibody labelled cells.

\section{$R T-P C R$}

Reverse transcription of RNA was carried out as previously described in [10]. The human annexin I primers used were as follows: upstream primer (position 84-112 (28 bp): GTA TCA GAA TTC CTC AAG CAG GCC TGG T) and downstream primer (position 1082-1110 (28 bp): TCC TCC ACA AAG AGC CAC CAG GAT TTT C). Primers for the control gene GAPDH were: 5' CGT CTT CAC CAC CAT GGA GA $3^{\prime}$ (forward); 5' CGG CCA TCA CGC CAC AGT TT 3' (reverse), yielding a PCR product of $300 \mathrm{bp}$. cDNA was amplified for 30 cycles using a DNA thermal cycler (Hybaid, Omnigene). Following PCR, the amplified products were analyzed on a $1.6 \%$ agarose gel containing ethidium bromide, with a size marker (123 bp ladder, Gibco BRL), and gel loading was normalized to GAPDH products. Differences in intensity of staining between treatment and controlderived RNA were confirmed with an image analyzing system (Kodak Digital EDAS).
Competitive RT-PCR was performed as described in [10]. Briefly, PCR MIMICs were generated by two successive PCR amplifications according to the PCR MIMIC construction kit (Clontech Laboratories, Inc, Palo Alto, Calif). Fourfold dilutions of each PCR MIMIC between $10^{-1}-10^{-2}$ attomole/mL were added to PCR amplification reactions containing a constant amount of the sample cDNA. The PCR amplification was performed in one cycle for 5 minutes at $95^{\circ} \mathrm{C}$, and in 26 cycles for denaturing at $94^{\circ} \mathrm{C}$ for 45 seconds, annealing at $55^{\circ} \mathrm{C}$ for 45 seconds and extending at $72^{\circ} \mathrm{C}$ for 90 seconds. To determine the amount of the target mRNA, PCR products were separated on a $1.6 \%$ agarose gel, and the intensity of staining was analyzed using computerized scanner and image analysis software (NIH Image). The concentration of the target mRNA was derived from the zero intersect of the log ratio of target to mimic PCR products [10].

\section{Statistical analysis}

The data are presented as mean \pm SEM and analyzed by Mann-Whitney $U$ test or Student $t$ test. Values of $P<.05$ were regarded as statistically significant. Group sizes referred to in the text refer to numbers of experiments; in each case each experiment was performed with cells from a different donor.

\section{RESULTS}

\section{Effect of DEX on FLS annexin I}

To investigate the expression and regulation of annexin I in FLS, annexin I mRNA was measured using competitive RTPCR. Annexin I mRNA was constitutively expressed in RA FLS (Figure 1). DEX induced increased annexin I mRNA in RA synovial fibroblasts at 24 hours (Figure 1). In contrast, intracellular annexin I was inhibited by DEX, exhibiting a trend towards a significant reduction after 3 hours exposure to $\operatorname{DEX}\left(\mathrm{MFI}\left(\times 10^{3}\right): 1.7 \pm 0.1 \mathrm{cf} 1.5 \pm 0.2, P=.057\right)$ and a significant reduction at 24 hours (MFI: $1.8 \pm 0.3 \mathrm{cf}$ $1.4 \pm 0.3, n=6, P<.01$ ) (Figure 2 ). In contrast to the reduction in intracellular annexin I protein, DEX treatment increased cell surface annexin I at 3 hours and 24 hours (Figure 3). These data suggest that DEX induces the translocation of intracellular annexin I to the cell surface, followed by increased expression of annexin I mRNA. A smaller $33 \mathrm{kD}$ fragment, previously shown to be a glucocorticoid-inducible fragment of annexin I [14], was also shown to be increased by DEX.

\section{Effect of interleukin-1ß on FLS annexin I}

Treatment with IL-1 $\beta$ also increased FLS annexin I mRNA (Figure 4 ). IL-1 $\beta$ treatment also increased RA FLS cell surface annexin I (Figure 5). In contrast to the effect of DEX, however, IL- $1 \beta$ significantly increased intracellular annexin I protein as well as cell surface annexin I, in comparison with control (Figure 6) $(P=.007)$. 


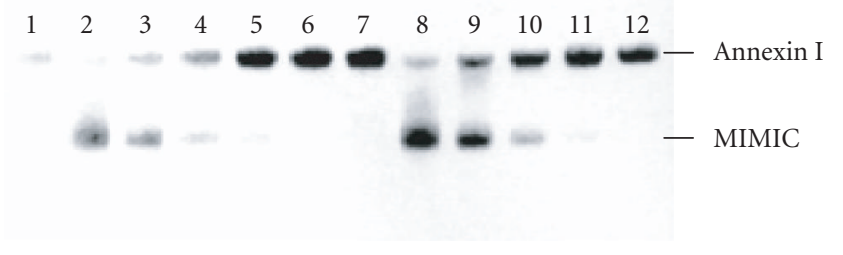

(a)

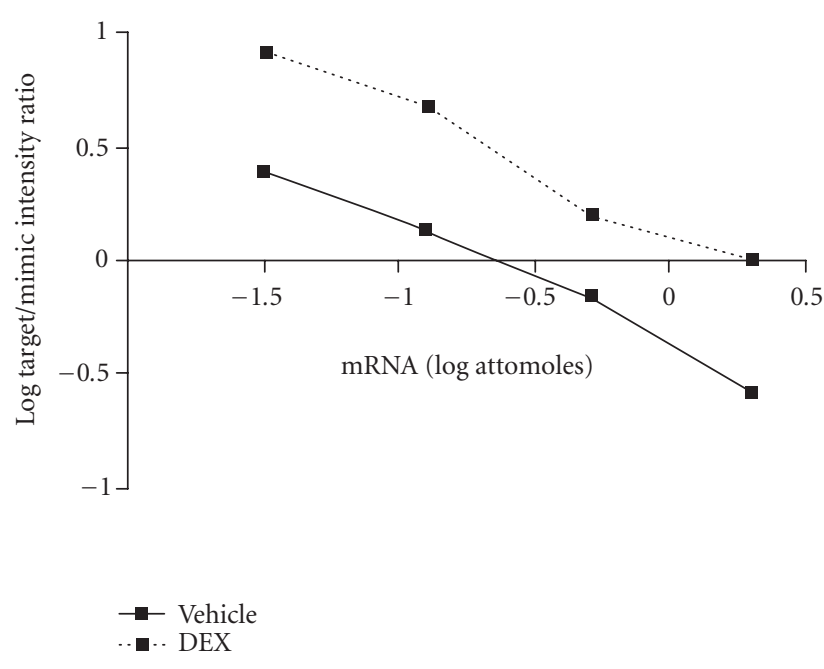

(b)

FIGURE 1: DEX effects on RA synovial fibroblast annexin I mRNA. Panel (a): RNA extracted from human RA FLS was subjected to competitive RT-PCR with (lanes 2-6 and 8-12) or without (lanes 1 and 7) mimic. Lanes 1-6: control; lanes 7-12: DEX $10^{-7} \mathrm{M}$ for 24 hours. Annexin I mRNA content was greater in DEX-treated than vehicle-treated cells. Representative of $n=4$ separate experiments from 4 separate RA donors. Panel (b): the log of the ratios of the annexin I and mimic PCR product band intensities were graphed as a function of the log of the amount of mimic added to the reaction. Increased annexin I mRNA is seen in DEX-treated RA synovial fibroblasts. Representative of $n=4$ separate experiments from 4 separate RA donors.

\section{Interaction of DEX and IL-1 $\beta$ on FLS annexin I}

To assess whether the effects of glucocorticoid and IL- $1 \beta$ on FLS annexin I synthesis were additive, cells were cotreated with DEX and IL- $1 \beta$. Annexin I mRNA was markedly and dose-dependently increased by the combination of DEX and IL- $1 \beta \mathrm{s}$, with significantly greater annexin I expression observed when compared to either IL- $1 \beta$ or DEX alone (Figure 4). Surprisingly, the addition of DEX to IL- $1 \beta$ led to inhibition of cell surface annexin I compared to either alone or untreated cells (Figure 5). These results suggest that the effects of IL-1 on cell surface annexin I are inhibited by DEX, despite DEX being an inducer of cell surface annexin I in its own right. The addition of DEX to IL- $1 \beta$ also led to reduced intracellular annexin I protein compared to IL$1 \beta$ alone $(P<.05)$ (Figure 6$)$, suggesting that increase in annexin I mRNA with combination of DEX and IL-1 was

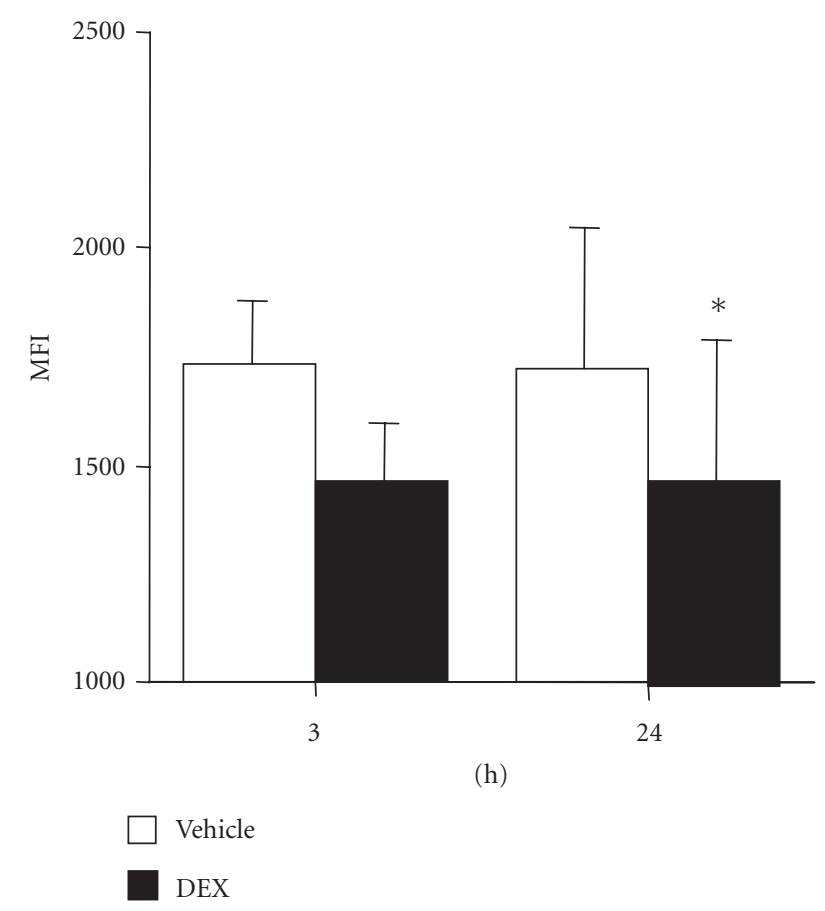

Figure 2: DEX effects on RA synovial fibroblast intracellular annexin I. Annexin I protein was detected in cultured RA FLS by permeabilization flow cytometry and displayed as mean \pm SEM mean fluorescence intensity (MFI). Compared to control (open bars), cells treated with DEX $10^{-7} \mathrm{M}$ (filled bars) exhibited reduced intracellular annexin I at 3 hours and 24 hours, respectively $(n=6)$. ${ }^{*} P<.05$.

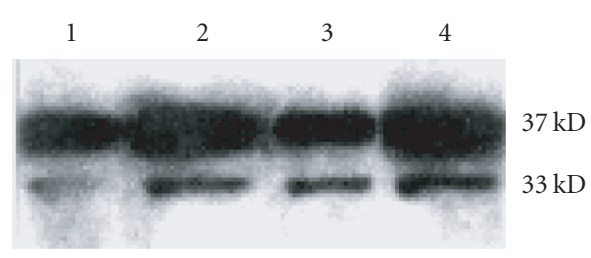

FIGURE 3: DEX effects on RA synovial fibroblast cell surface annexin I. RA FLS were exposed to DEX $10^{-7} \mathrm{M}$ for 3 hours and 24 hours, respectively. Cell surface annexin I was detected by Western blotting. Lanes 1 and 2 show 3-hour control, and DEX-treated cell surface eluates, lanes 3 and 4 show 24-hour control, and DEX-treated cell surface eluates. A $37 \mathrm{kD}$ band representing full-length annexin I was increased at 3 hours and increased further at 24 hours in DEX. A smaller $33 \mathrm{kD}$ fragment of annexin I was also increased by DEX. Data presented are from one experiment representative of $n=4$.

inhibited post-transcriptionally leading to increase in annexin I protein.

\section{DISCUSSION}

The very broad range of antiinflammatory effects of annexin I [7, 14, 22-24] suggests its potential as an endogenous and glucocorticoids induced antiinflammatory regulator in a disease such as RA. Antagonism of annexin I 


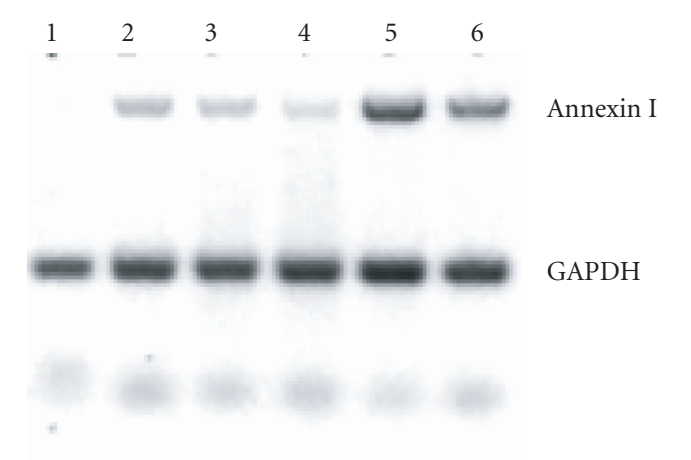

FIgURE 4: IL-1 $\beta$ and DEX effects on RA synovial fibroblast annexin I mRNA. RA FLS were exposed to IL- $1 \beta 1 \mathrm{ng} / \mathrm{mL}$ and DEX $10^{-7}$ $10^{-8} \mathrm{M}$ for 24 hours and annexin I mRNA measured by semiquantitative RT-PCR. Upper bands: annexin I, lower bands: GAPDH. Lane 1: control; lane 2: DEX $10^{-7} \mathrm{M}$; lane 3: DEX $10^{-8} \mathrm{M}$; lane 4: IL- $1 \beta 1 \mathrm{ng} / \mathrm{mL}$; lane 5 : IL- $1 \beta$ plus DEX $10^{-7} \mathrm{M}$; lane 6 : IL- $1 \beta$ plus DEX $10^{-8} \mathrm{M}$. DEX and IL- $1 \beta$ both induced annexin I mRNA. Cotreatment with DEX and IL- $1 \beta$ had additive effects on annexin I mRNA. Data presented are from one experiment representative of $n=4$.

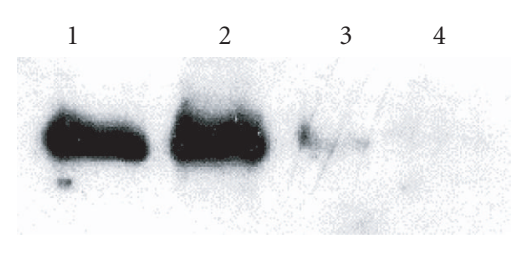

FIGURE 5: IL- $1 \beta$ and DEX effects on RA synovial fibroblast cell surface annexin I. RA FLS were exposed to IL- $1 \beta 1 \mathrm{ng} / \mathrm{mL}$ and DEX $10^{-7}-10^{-8} \mathrm{M}$ for 24 hours. Cell surface annexin I was detected by Western blotting. Lane 1 and 2 show control, and IL- $1 \beta$-treated cells, lane 3 and 4 show IL- $1 \beta+\operatorname{DEX}\left(10^{-7}\right.$ and $\left.10^{-8} \mathrm{M}\right)$-treated cells. Cell surface annexin I was increased by IL-1 $\beta$. Cotreatment with DEX and IL- $1 \beta$ inhibited cell surface annexin I. Data presented are from one experiment representative of $n=3$.

exacerbates rat adjuvant and carrageenan-induced arthritis $[9,10]$, and in adjuvant arthritis, this is associated with increased synovial prostaglandin $E_{2}$ and TNF- $\alpha$ [10]. Moreover, in both models, antagonism of annexin I prevents the effects of exogenous glucocorticoids. Recent studies demonstrated that disruption of the Anx-1 gene in mice exacerbated arthritis severity and proinflammatory cytokine expression in antigen-induced arthritis [16]. The absence of Anx-1 was also associated with insensitivity to the antiinflammatory effects of dexamethasone, indicating a major role for Anx-1 in the pathopharmacology of inflammation [16]. Annexin I has been demonstrated in human peripheral blood leukocytes and in RA synovium [12, 13], and annexin I cell surface binding sites have been demonstrated in RA FLS $[17,18]$. Synovial fibroblasts are important contributors to the pathology of RA, but the regulation of annexin I in human synovial cells by pro- and antiinflammatory mediators has not been previously reported.

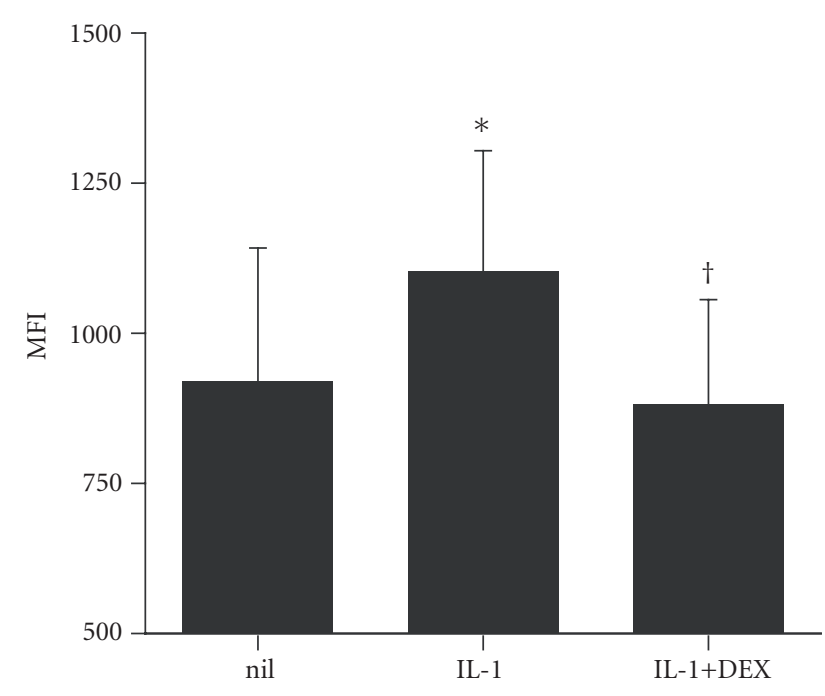

FIgURE 6: IL- $1 \beta$ and DEX effects on RA synovial fibroblast intracellular annexin I. RA FLS were cultured for 24 hours with interleukin$1 \beta$ (IL-1, $1 \mathrm{ng} / \mathrm{mL})$, and/or DEX (DEX, $\left.10^{-8} \mathrm{M}\right)$. Annexin I protein was detected by permeabilization flow cytometry and displayed as mean \pm SEM mean fluorescence intensity (MFI). IL- $1 \beta$ significantly increased intracellular annexin I $\left({ }^{*} P<.01\right)$. The addition of DEX $10^{-8} \mathrm{M}$ prevented the effect of IL- $1 \beta$ on intracellular annexin $\mathrm{I}(\dagger P<.05)(n=6)$.

In the current study, we demonstrate that RA FLS constitutively express annexin I. DEX induced annexin I mRNA, associated with a concomitant reduction in intracellular annexin I, and an increase in cell surface annexin I. The increased annexin I mRNA in cells treated with DEX suggests that the reduction in intracellular annexin I protein is not the result of reduced synthesis but rather of increased export to the cell surface. These data suggest that DEX first induces the translocation of pre-existing annexin I to the cell surface, followed by reconstitution via new mRNA expression.

The current results also demonstrate that IL- $1 \beta$ increases annexin I transcription, synthesis, and cell surface translocation in FLS. IL- $1 \beta$ induces $c$-jun/fos AP- 1 subunit activation in RA FLS [25], and as the annexin I promoter region contains an AP-1 site [26] this is likely to be involved in the response to IL-1 $\beta$. Induction of antiinflammatory proteins by pro-inflammatory stimuli such as IL- 1 is not surprising, as many molecules such as IL-10 are inducible by pro-inflammatory cytokines and participate in the regulatory control of inflammation. Given the positive effects of both DEX and IL- $1 \beta$, we anticipated an interaction between these stimuli on FLS annexin I. The combination of DEX and IL- $1 \beta$ additively induced annexin I mRNA consistent with additive effects on separate transcription factors. Surprisingly, however, the addition of DEX to IL-1 was associated with reductions in both intracellular and cell surface protein. Of note, IL- $1 \beta$ treatment did not induce the cell surface expression of the smaller $33 \mathrm{kD}$ annexin I fragment which was observed with DEX treatment. The discrepant effects of DEX and IL- $1 \beta$ on FLS intracellular annexin I protein suggests that the synthesis and cell surface translocation of 
annexin I are differently regulated by these two stimuli. These findings are consistent with the existence of differential posttranscriptional effects of DEX and IL- $1 \beta$ on annexin I synthesis. On the basis that the antiinflammatory effects of annexin I depend upon cell surface translocation [7], the prevention by IL- $1 \beta$ of DEX-induced annexin I surface translocation is consistent with cytokine-dependent limitation of annexin I in the setting of inflammation. In RA synovium, IL- $1 \beta$ is chronically overproduced, and thus the effect of physiological and pharmacological glucocorticoids on annexin I may be chronically and specifically inhibited. No data exists on the effects of specific IL-1 antagonism, for example, using recombinant IL-1RA products such as anakinra, on annexin I expression in human RA.

Although GC are effective agents in the treatment of RA, a proportion of patients with RA and other inflammatory diseases are resistant to their therapeutic effects. GC sensitivity has been reported to be associated with reduced GC receptor nuclear translocation [27], increased expression of GC receptor $\beta[28]$-migration inhibitory factor (Aeberli et al, FEBS Letters in press). Annexin I responses to GC may also potentially be associated with GC resistance. Certainly, leukocyte intracellular annexin I protein responses to glucocorticoids are impaired in RA patients [29], leukocytes and synovial fibroblast cell surface annexin I binding sites are reduced in RA patients [17, $18,30]$, and sensitivity to GC in arthritic mice is impaired in the absence of annexin I [16]. Annexin I expression is possibly an index for recognition of GC resistance. Direct links between annexin I and the complicated molecular mechanisms of GC resistance remain to be further investigated.

In conclusion, glucocorticoids and IL- $1 \beta$ each increases the expression and cell surface translocation of annexin I in human RA FLS. Discrepant effects of combined DEX and IL$1 \beta$ suggest post-transcriptional interactions. Further studies are required to define the mechanisms of cell surface translocation of annexin I, the signaling pathways involved in glucocorticoid and cytokine regulation of synoviocyte annexin $\mathrm{I}$, and the mechanism(s) of antiinflammatory action of annexin I.

\section{CONCLUSION}

Annexin I is an important antiinflammatory protein, shown here to be constitutively expressed in human RA synoviocytes. The upregulation of synoviocyte annexin I by DEX supports the hypothesis that annexin I is involved in the physiological and pharmacological effects of glucocorticoids in RA. The discrepant effects of IL- $1 \beta$ in the presence and absence of DEX suggest differential regulation of annexin I transcription, synthesis, and translocation.

\section{REFERENCES}

[1] Laan RF, Jansen TL, van Riel PL. Glucocorticosteroids in the management of rheumatoid arthritis. Rheumatology (Oxford). 1999;38(1):6-12.
[2] Barnes PJ. Anti-inflammatory actions of glucocorticoids: molecular mechanisms. Clinical Science (London). 1998;94(6): 557-572.

[3] Yang YH, Hutchinson P, Leech M, Morand EF. Exacerbation of adjuvant arthritis by adrenalectomy is associated with reduced leukocyte lipocortin 1. The Journal of Rheumatology. 1997;24(9):1758-1764.

[4] Philip JG, Flower RJ, Buckingham JC. Glucocorticoids modulate the cellular disposition of lipocortin 1 in the rat brain in vivo and in vitro. Neuroreport. 1997;8(8):1871-1876.

[5] Comera C, Russo-Marie F. Glucocorticoid-induced annexin 1 secretion by monocytes and peritoneal leukocytes. British Journal of Pharmacology. 1995;115(6):1043-1047.

[6] Perretti M, Flower RJ. Modulation of IL-1-induced neutrophil migration by dexamethasone and lipocortin 1. Journal of Immunology. 1993;150(3):992-999.

[7] Perretti M, Croxtall JD, Wheller SK, Goulding NJ, Hannon R, Flower RJ. Mobilizing lipocortin 1 in adherent human leukocytes downregulates their transmigration. Nature Medicine. 1996;2(11):1259-1262.

[8] Perretti M, Ahluwalia A, Harris JG, Harris HJ, Wheller SK, Flower RJ. Acute inflammatory response in the mouse: exacerbation by immunoneutralization of lipocortin 1. British Journal of Pharmacology. 1996;117(6):1145-1154.

[9] Yang YH, Leech M, Hutchinson P, Holdsworth SR, Morand EF. Antiinflammatory effect of lipocortin 1 in experimental arthritis. Inflammation. 1997;21(6):583-596.

[10] Yang YH, Hutchinson P, Morand EF. Inhibitory effect of annexin I on synovial inflammation in rat adjuvant arthritis. Arthritis and Rheumatism. 1999;42(7):1538-1544.

[11] Solito E, Romero IA, Marullo S, Russo-Marie F, Weksler BB. Annexin 1 binds to U937 monocytic cells and inhibits their adhesion to microvascular endothelium: involvement of the alpha 4 beta 1 integrin. Journal of Immunology. 2000;165(3): 1573-1581.

[12] Morand EF, Hutchinson P, Hargreaves A, Goulding NJ, Boyce NW, Holdsworth SR. Detection of intracellular lipocortin 1 in human leukocyte subsets. Clinical Immunology and Immunopathology. 1995;76(2):195-202.

[13] Goulding NJ, Dixey J, Morand EF, et al. Differential distribution of annexins-I, -II, -IV, and -VI in synovium. Annals of the Rheumatic Diseases. 1995;54(10):841-845.

[14] Yang YH, Hutchinson P, Santos LL, Morand EF. Glucocorticoid inhibition of adjuvant arthritis synovial macrophage nitric oxide production: role of lipocortin 1. Clinical and Experimental Immunology. 1998;111(1):117-122.

[15] Yang YH, Hall P, Milenkovski G, et al. Reduction in arthritis severity and modulation of immune function in tissue factor cytoplasmic domain mutant mice. The American Journal of Pathology. 2004;164(1):109-117.

[16] Yang YH, Morand EF, Getting SJ, et al. Modulation of inflammation and response to dexamethasone by Annexin 1 in antigen-induced arthritis. Arthritis and Rheumatism. 2004;50 (3):976-984.

[17] Sampey AV, Hutchinson P, Morand EF. Annexin I and dexamethasone effects on phospholipase and cyclooxygenase activity in human synoviocytes. Mediators of Inflammation. 2000;9(34):125-132.

[18] Sampey AV, Hutchinson P, Morand EF. Annexin I surface binding sites and their regulation on human fibroblast-like synoviocytes. Arthritis and Rheumatism. 2000;43(11):25372542.

[19] Arnett FC, Edworthy SM, Bloch DA, et al. The American Rheumatism Association 1987 revised criteria for the 
classification of rheumatoid arthritis. Arthritis and Rheumatism. 1988;31(3):315-324.

[20] Leech M, Metz C, Hall P, et al. Macrophage migration inhibitory factor in rheumatoid arthritis: evidence of proinflammatory function and regulation by glucocorticoids. Arthritis and Rheumatism. 1999;42(8):1601-1608.

[21] Morand EF, Hutchinson P, Boyce NW, Goulding NJ, Holdsworth SR. Expression of intracellular lipocortin 1 in human peripheral blood leukocyte subsets. AustNZJMed. 1995; 25:405.

[22] Cirino G, Flower RJ. Human recombinant lipocortin 1 inhibits prostacyclin production by human umbilical artery in vitro. Prostaglandins. 1987;34(1):59-62.

[23] Gold R, Pepinsky RB, Zettl UK, Toyka KV, Hartung HP. Lipocortin-1 (annexin-1) suppresses activation of autoimmune T cell lines in the Lewis rat. Journal of Neuroimmunology. 1996;69(1-2):157-164.

[24] Kim KM, Kim DK, Park YM, Kim CK, Na DS. Annexin-I inhibits phospholipase A2 by specific interaction, not by substrate depletion. FEBS Letters. 1994;343(3):251-255.

[25] Barchowsky A, Frleta D, Vincenti MP. Integration of the NFkappaB and mitogen-activated protein kinase/AP-1 pathways at the collagenase-1 promoter: divergence of IL-1 and TNFdependent signal transduction in rabbit primary synovial fibroblasts. Cytokine. 2000;12(10):1469-1479.

[26] Browning JL, Ward MP, Wallner BP, Pepinsky RB. Studies on the structural properties of lipocortin-1 and the regulation of its synthesis by steroids. Progress in Clinical and Biological Research. 1990;349:27-45.

[27] Bloom JW. Mitogen-activated protein kinase pathways: therapeutic targets in steroid resistance? The Journal of Allergy and Clinical Immunology. 2004;114(5):1055-1058.

[28] Derijk RH, Schaaf MJ, Turner G, et al. A human glucocorticoid receptor gene variant that increases the stability of the glucocorticoid receptor beta-isoform mRNA is associated with rheumatoid arthritis. The Journal of Rheumatology. 2001;28(11):2383-2388.

[29] Morand EF, Jefferiss CM, Dixey J, Mitra D, Goulding NJ. Impaired glucocorticoid induction of mononuclear leukocyte lipocortin-1 in rheumatoid arthritis. Arthritis and Rheumatism. 1994;37(2):207-211.

[30] Goulding NJ, Jefferiss CM, Pan L, Rigby WF, Guyre PM. Specific binding of lipocortin-1 (annexin I) to monocytes and neutrophils is decreased in rheumatoid arthritis. Arthritis and Rheumatism. 1992;35(11):1395-1397. 


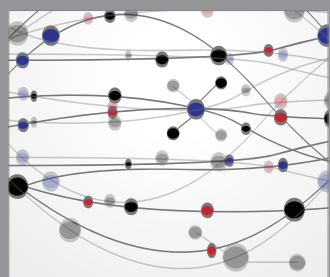

The Scientific World Journal
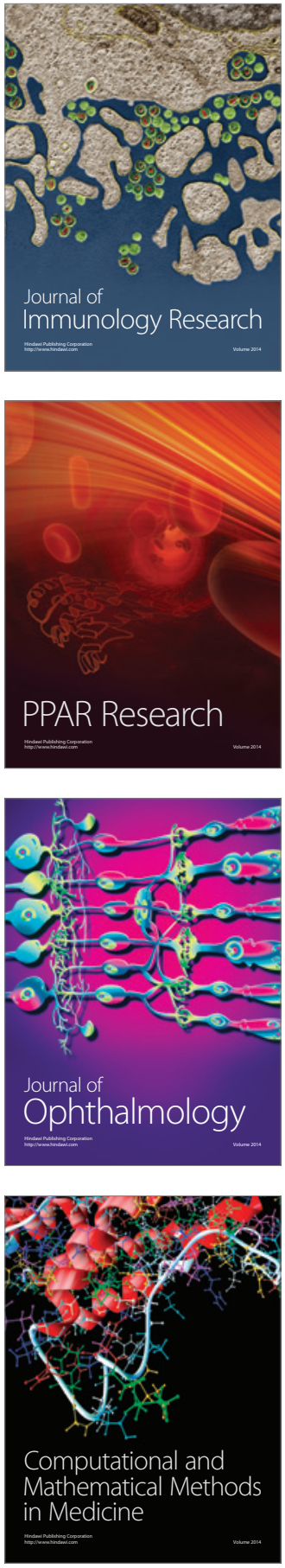

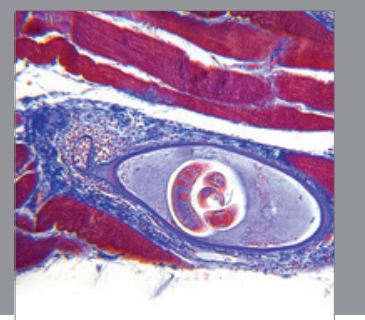

Gastroenterology

Research and Practice
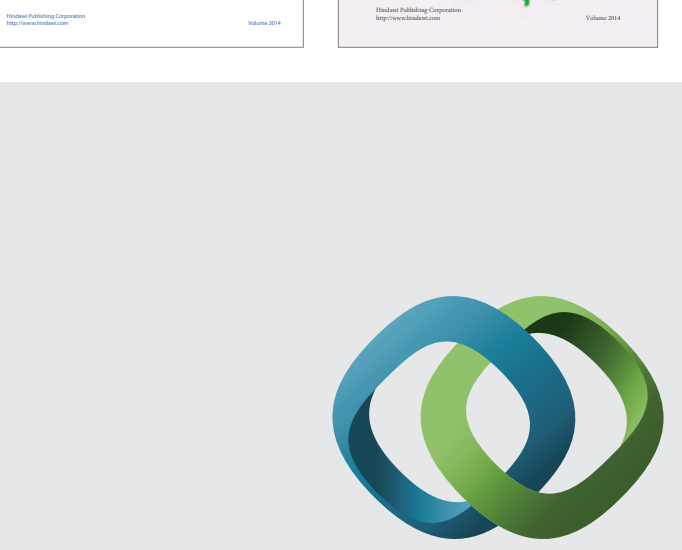

\section{Hindawi}

Submit your manuscripts at

http://www.hindawi.com
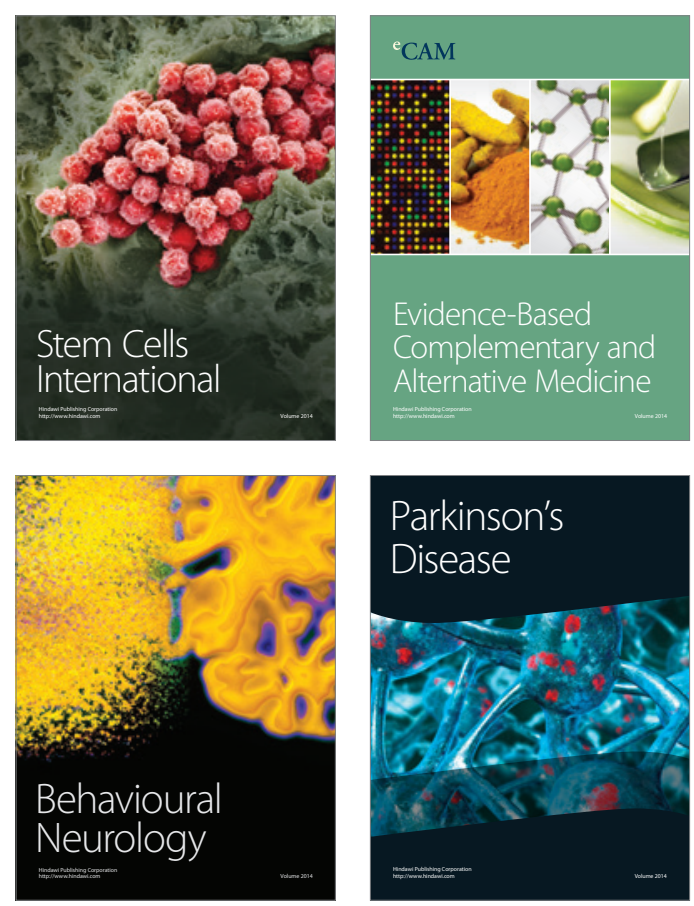

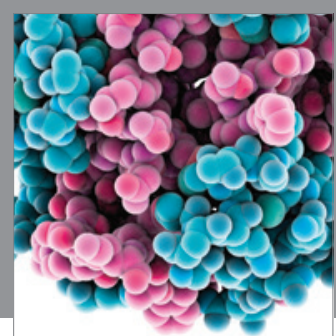

Journal of
Diabetes Research

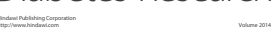

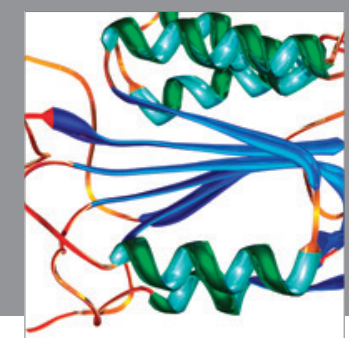

Disease Markers
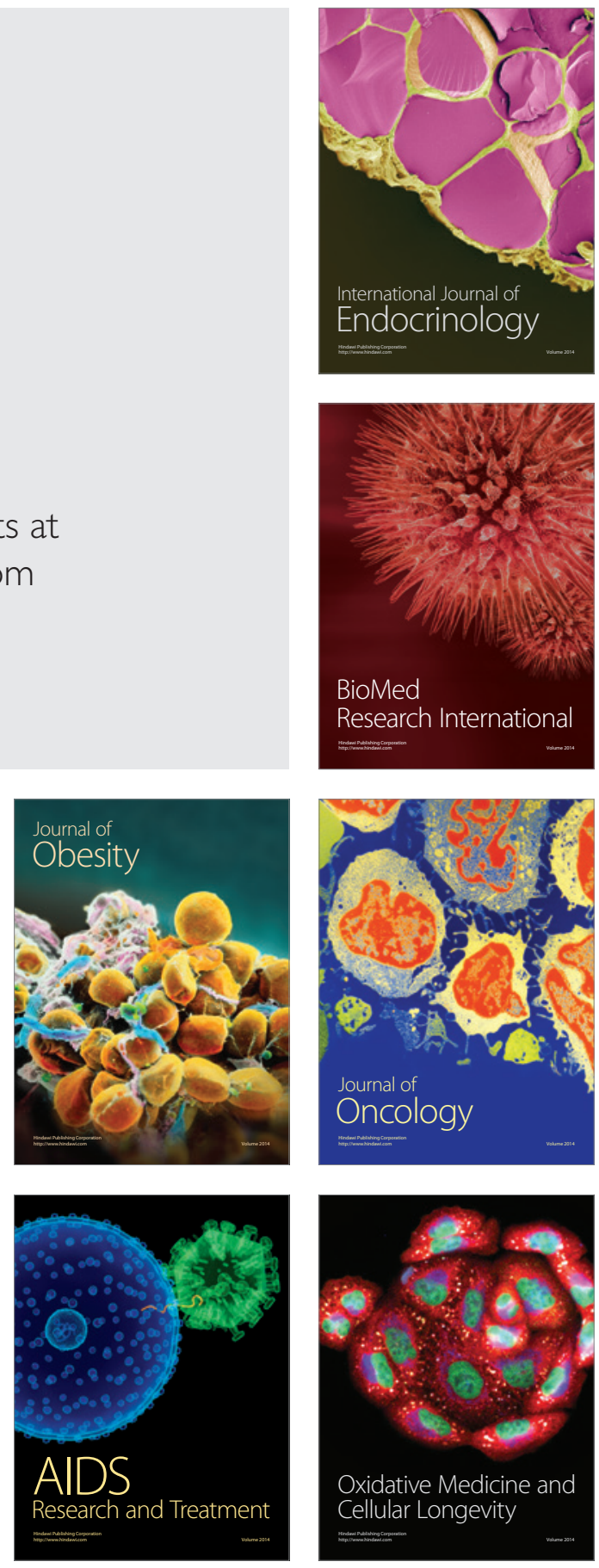